\title{
Effect of Organic Acid Salts and Chitosan on Case-Ready Packed Ground Beef and Pork Patties
}

\author{
Seon Hee Park, Seung Hee Chung ${ }^{1}$, Sung Ki Lee ${ }^{2}$, and Keun Taik Lee* \\ Department of Food Science, Gangneung-Wonju National University, Gangneung 210-702, Korea \\ ${ }^{1}$ GO Foodtech Institute, Seongnam 463-741, Korea \\ ${ }^{2}$ Department of Animal Products and Food Science, Kangwon National University, Chuncheon 200-701, Korea
}

\begin{abstract}
The effects of ascorbic acid (AA) alone or in combination with sodium acetate/calcium lactate (AA+SACL) and chitosan $(\mathrm{AA}+\mathrm{CH})$ on the physicochemical properties and microbial growth of beef and pork patties stored at $5^{\circ} \mathrm{C}$ were investigated. The patties were case-ready packed in an air-containing polypropylene (PP) tray and sealed with polyethylene terephthlate (PETP)/casted polypropylene (CPP) top film. Treatments with AA, AA+SACL and AA+CH were effective in inhibiting total aerobic bacteria from day 4 compared to the control. In general, thiobarbituric acid, volatile basic nitrogen, and hue values in treated samples were lower than the control over the storage, whereas Hunter $a^{*}$ (redness) values and sensory scores for surface color and off-odor were higher. Regarding quality and shelf-life extension, ground beef and pork patties treated with $\mathrm{AA}+\mathrm{SACL}$ produced the most desirable results among all treatments during storage.
\end{abstract}

Key words: ascorbic acid, acetate and lactate, chitosan, patties, shelf-life

\section{Introduction}

When the meats are ground, a greater surface area is exposed to air and microbial contamination. Therefore, meat patties become more susceptible to quality changes induced by oxidation and microbial growth than intact muscle cuts. As a result, the development of metmyoglobin and off-odor are likely to deter consumers of packaged ground meat patties. Color is the primary quality attribute indicating the freshness of meat products in a case-ready (CR) package influencing consumer choice at the store. Then, after opening the package, consumers tend to judge freshness by sniffing the odor from the product. Various attempts have been made to improve the problems related to discoloration and microbial growth and to extend the shelf-life of meat patties (Hayes et al., 2010; Lund et al., 2007; Stubbs et al., 2002). Recently, however, meat product manufacturers have increasingly taken to using organic acids including ascorbic acid, lactic acid, acetic acid, and their salts, because they are

\footnotetext{
*Corresponding author: Keun Taik Lee, Department of Food Science, Gangneung-Wonju National University, Gangneung 210-702, Korea. Tel: 82-33-640-2333, Fax: 82-33-647-4559, E-mail: leekt@gwnu.ac.kr
}

widely available, economical, and are recognized as GRAS substances (McWilliam Leitch and Stewart, 2002).

It was reported that $0.05 \%$ ascorbic acid treatment in ground beef could retard discoloration and rancidity at least for $5 \mathrm{~d}$ (Mitsumoto et al., 1991). Therefore, the use of ascorbic acid is recommended in the recipe of the meat patties when considering price, nutritional value and antioxidant effects. Furthermore, it will be interesting to examine the use of chitosan for meat products because of its useful effects on the antibacterial, antioxidant and other functional properties (Knorr, 1982; Razdan et al., 1994; Sagoo et al., 2002; Soultos et al., 2008).

Applications of organic salts such as lactate and acetate have been examined and are now commercialized for improving color stability, enhancing flavor, and retarding microbial growth in meat and meat products (Jensen et al., 2003; Smulders and Greer, 1998; Suman et al., 2010). Lactates are known to promote color stability. For instance, calcium lactate increased color stability and decreased metmyoglobin formation in beef steaks (Lawrence et al., 2004). Sodium acetate was superior to any lactate in stabilizing ground beef color (Seyfert et al., 2007). Calcium lactate increased color stability and decreased metmyoglobin formation in beef steaks (Lawrence et al., 2004). However, more studies are still 
needed to find the optimum usage level and mixing ratio of organic salts with other additives which are dependent on factors including product type, formulation recipe of raw material and ingredients, and processing conditions etc.

For marketing meat patties in Korea, ground meats are generally delivered from factory to retail stores after vacuum packaging, and then formed on-site into patties and packaged in a styrofoam tray overwrapped with polyvinyl chloride film for sale. However, case-ready (CR) packaging is becoming increasingly important in order to assure the hygiene and the traceability of the meat products. In particular, CR packaging is justified on the basis that ground meat products are associated with a higher level of health risk than are intact muscle cuts (Eilert, 2005). In the US, ground beef penetrated the CR market more rapidly than intact beef or pork cuts. In 2004, CR packaged products captured $66 \%$ of the ground beef market, while beef cuts captured only 23\% (Belcher, 2006). CR meats are usually packed in high oxygen modified atmosphere (MA) with barrier films (Belcher, 2006). However, unlike the USA and EU countries, Korea does not yet have an established market for CR packed patties in MA, probably because of the high investment and operation costs required. Besides, due to the recent worldwide economic crisis, local producers of patty products are trying to reduce production costs, for example, by the partial substitution of beef with cheap pork. Nevertheless, they are eager to seek a way to extend the shelf-life of products as long as possible while meeting the consumer demand. However, the effect of antioxidant and antimicrobial additives on the beef and pork mixed patties in an aircontaining package has rarely been examined (Rojas and Brewer, 2007). Therefore, we examined the effects of several organic acids and salts, and chitosan on the physical and chemical properties, and microbial growth in beef and pork patties during chilled storage, when packed in an air-containing PP tray as a CR packaging.

\section{Materials and Methods}

\section{Manufacturing and packaging of patties}

Vacuum packaged frozen beef (chuck) imported from Australia was thawed overnight in a $10^{\circ} \mathrm{C}$ chill room and ground through a $8 \mathrm{~mm}$ hole plate by meat grinder (622, Mado Co., Switzerland). Vacuum packaged fresh pork (hams), about 1 wk post-mortem, was supplied by a local meat packer (Bodam Co., Korea) was ground through a 3 $\mathrm{mm}$ hole plate. Ground beef and pork (ratio: 3:2(w/w)) were thoroughly mixed within a mixer (Thematec Food Ind., Co., Korea) after adding $0.3 \% \mathrm{NaCl}, 0.2 \%$ sodium tripolyphosphate, $4.0 \%$ hardtack powder, and $21 \%$ spices and seasonings. Five kilograms of ground meat products were then vacuum packaged in a polyamide/polyethylene laminated pouch $\left(15 / 85 \mu \mathrm{m}, \mathrm{O}_{2}\right.$ Permeability: $40 \mathrm{~mL} / \mathrm{m}^{2} /$ $24 \mathrm{~h} / \mathrm{atm}$ at $23^{\circ} \mathrm{C}$ ). Twenty-five kilograms of sample meat in 5 pouches were then transferred in an ice-box (ICDC260, Olivo, France) maintained at $+1{ }^{\circ} \mathrm{C}$ for approximately $4 \mathrm{hrs}$ to the laboratory.

The samples were allocated to 5 treatments as following: (i) control (CON) added with $\mathrm{NaCl}$, phosphates, hardtack powder, and spices and seasonings, (ii) T-1 (AA): (i)+ L-ascorbic acid (Junsei Chemical Co., Ltd., Japan) 500 ppm, (iii) T-2 (AA+SACL): (ii)+sodium acetate (Showa Chemical Co., Ltd., Japan) 1,500 ppm+calcium lactate (Daejung Chemical and Metals Co., Ltd., Japan) 500 ppm, and (iv) T-3 (AA+CH): (ii)+chitosan (polymeric type, $\mathrm{Mw}=640,000$; KL-245, Kitolife Co., Korea) 7,000 ppm. The ground meats were formed into $150 \mathrm{~g}$ patties with a circular template $(\mathrm{d}=10 \mathrm{~cm}$ and 1.8 $\mathrm{cm}$ in depth) and wrapped with a $30 \mu \mathrm{m}$ thick low density polyethylene film (LDPE) $\left(\mathrm{O}_{2}\right.$ permeability: 4,730 mL/ $\mathrm{m}^{2} / 24 \mathrm{~h}$ at $23^{\circ} \mathrm{C}$ ). Then, a patty was placed on a $65 \mu \mathrm{m}$ thick PP tray and sealed with PETP/CPP laminated film (12/40 $\mu \mathrm{m}, \mathrm{O}_{2}$ permeability: $92 \mathrm{~mL} / \mathrm{m}^{2} / 24 \mathrm{~h}$ at $\left.23^{\circ} \mathrm{C}\right)$. Packaged patties were stored in the dark at $5^{\circ} \mathrm{C}$ for $10 \mathrm{~d}$ and were analyzed periodically every $2 \mathrm{~d}$.

\section{Microbiology}

Total aerobic bacteria (Standard-1 agar, Merck), Pseudomonas spp. (GSP agar, Merck), lactic acid bacteria (MRS agar, Merck), and coliform bacteria (3M) were determined during storage of the patties. Ten grams of sample were cut off from the rim of each patty and mixed for $3 \mathrm{~min}$ in the Stomacher (Stomacher 80, Seward Medical, UK) after adding 9 parts of $0.1 \%$ sterilized peptonewater. The procedure for the sample preparation, inoculation and incubation was followed according to the method of Lee and Yoon (2001).

\section{Physicochemical analysis}

Hunter $L^{*}$ (lightness), $a^{*}$ (redness) and $b^{*}$ (yellowness), and hue $(\operatorname{arc} \tan b / a)$ values were measured on the surfaces of the raw patties immediately upon opening the package using a color difference meter (CR-300, Minolta Co., Japan) with a $38 \mathrm{~mm}$ diameter aperture. D65 illuminant and standard $10^{\circ}$ observer were used for measuring color characteristics. $\mathrm{pH}$ was measured using a combined 
Table 1. Conditions of Gas Chromatography for gas analysis

\begin{tabular}{ll}
\hline \hline Column & Carboxen-1000 (Supelco) \\
Detector & TCD \\
Detector temp. & $300^{\circ} \mathrm{C}$ \\
& Held at $30^{\circ} \mathrm{C}$ for 7 min and programmed \\
Oven temp. & to $300^{\circ} \mathrm{C}$ at $10^{\circ} \mathrm{C} / \mathrm{min}$. \\
Carrier gas & $\mathrm{He}(35 \mathrm{psi}$, total flow $50 \mathrm{~mL} / \mathrm{min})$ \\
Injection & $100 \mu \mathrm{L}, 30^{\circ} \mathrm{C}$, splitless \\
\hline
\end{tabular}

glass electrode (720A, Orion, USA). Changes in the TBA (thiobarbituric acid) were used to assess lipid oxidation according to the method of Witte et al. (1970). The VBN (volatile basic nitrogen) test using the microdiffusion technique of Conway (1958) was used to determine proteolytic degradation. Samples of ground meat approximately $1 \mathrm{~cm}$ thick were collected for TBA and VBN tests. Gas composition $\left(\mathrm{O}_{2}, \mathrm{~N}_{2}\right.$ and $\left.\mathrm{CO}_{2}\right)$ in the headspace of the package was monitored by using a gas chromatography (7890A, Agilent Technologies, Germany) fitted with a TCD detector. The analysis conditions of gas chromatography are shown in Table 1 .

\section{Sensory evaluations}

A trained, 8-10 member panel composed of faculty members and students in the meat processing laboratory of Gangneung-Wonju University evaluated raw patty samples using a 9-point hedonic scale for discoloration (9: none, to 1: total) and off-odor (9: none, to 1: extreme). Panelists were experienced in evaluating and tasting ground meat patties. The samples for sensory evaluation were presented in PP trays identified with three-digit random numbers, which were illuminated under natural fluorescent light, positioned so that it provided 1,200 luxes at the surface of sample. Shelf-life for marketability was defined as the point of time when the sensory score was evaluated below 5.0.

\section{Statistical methods}

Data were analyzed using SPSS statistical program (Ver. 14, SPSS Inc., USA). Furthermore, Duncan's multiple range test was used to compare means and significance which was established at $p<0.05$.

\section{Results and Discussion}

\section{Microbiology}

The microbiological changes of beef and pork patties during storage at $5^{\circ} \mathrm{C}$ are presented in Table 2 . The total aerobic plate count (TPC) was initially $4.81 \mathrm{log} \mathrm{cfu} / \mathrm{g}$ which increased steadily with the storage and reached close to $8.0 \mathrm{log} \mathrm{cfu} / \mathrm{g}$ at days 8 and 10 in the $\mathrm{CON}$ and treated samples, respectively. The TPC was significantly

Table 2. Changes in microbes of case-ready packaged beef and pork patties treated with different additives during storage at $5^{\circ} \mathrm{C}$

Unit: $\log \mathrm{cfu} / \mathrm{g}$

\begin{tabular}{|c|c|c|c|c|c|c|c|}
\hline \multirow{2}{*}{ Microbes } & \multirow{2}{*}{ Treatment ${ }^{1)}$} & \multicolumn{6}{|c|}{ Storage time (d) } \\
\hline & & 0 & 2 & 4 & 6 & 8 & 10 \\
\hline \multirow{4}{*}{ Total aerobes } & $\mathrm{CON}$ & $4.81^{\mathrm{Aa}}$ & $5.08^{\mathrm{Ab}}$ & $5.93^{\mathrm{Dc}}$ & $6.73^{\mathrm{Cd}}$ & $7.85^{\mathrm{Ce}}$ & $8.76^{\mathrm{Cf}}$ \\
\hline & $\mathrm{AA}$ & $4.81^{\mathrm{Aa}}$ & $5.07^{\mathrm{Ab}}$ & $5.68^{\mathrm{Bc}}$ & $6.08^{\mathrm{Ad}}$ & $6.91^{\mathrm{Be}}$ & $7.89^{\mathrm{Bf}}$ \\
\hline & $\mathrm{AA}+\mathrm{SACL}$ & $4.81^{\mathrm{Aa}}$ & $4.94^{\mathrm{Aa}}$ & $5.54^{\mathrm{Ab}}$ & $6.04^{\mathrm{Ac}}$ & $6.48^{\mathrm{Ad}}$ & $7.80^{\mathrm{Ae}}$ \\
\hline & $\mathrm{AA}+\mathrm{CH}$ & $4.81^{\mathrm{Aa}}$ & $5.06^{\mathrm{Ab}}$ & $5.86^{\mathrm{Cc}}$ & $6.15^{\mathrm{Bd}}$ & $6.95^{\mathrm{Be}}$ & $7.90^{\mathrm{Bf}}$ \\
\hline \multirow{4}{*}{$\begin{array}{l}\text { Lactic acid } \\
\text { bacteria }\end{array}$} & $\mathrm{CON}$ & $4.63^{\mathrm{Aa}}$ & $4.84^{\mathrm{Bb}}$ & $5.58^{\mathrm{Cc}}$ & $6.11^{\mathrm{Dd}}$ & $6.30^{\mathrm{De}}$ & $7.42^{\mathrm{Df}}$ \\
\hline & $\mathrm{AA}$ & $4.63^{\mathrm{Aa}}$ & $4.83^{\mathrm{Bb}}$ & $5.47^{\mathrm{Cc}}$ & $5.92^{\mathrm{Cd}}$ & $6.00^{\mathrm{Cd}}$ & $6.97^{\mathrm{Ce}}$ \\
\hline & $\mathrm{AA}+\mathrm{SACL}$ & $4.63^{\mathrm{Aa}}$ & $4.73^{\mathrm{Ba}}$ & $5.29^{\mathrm{Bb}}$ & $5.84^{\mathrm{Bc}}$ & $5.62^{\mathrm{Ad}}$ & $6.41^{\mathrm{Be}}$ \\
\hline & $\mathrm{AA}+\mathrm{CH}$ & $4.63^{\mathrm{Aa}}$ & $4.56^{\mathrm{Aa}}$ & $5.15^{\mathrm{Ab}}$ & $5.35^{\mathrm{Ac}}$ & $5.88^{\mathrm{Bd}}$ & $6.28^{\mathrm{Ae}}$ \\
\hline \multirow{4}{*}{ Pseudomonas } & $\mathrm{CON}$ & $3.40^{\mathrm{Aa}}$ & $3.76^{\mathrm{Ba}}$ & $4.41^{\mathrm{Cc}}$ & $4.74^{\mathrm{Bd}}$ & $5.09^{\mathrm{BCe}}$ & $5.96^{\mathrm{Cf}}$ \\
\hline & AA & $3.40^{\mathrm{Aa}}$ & $3.61^{\mathrm{ABb}}$ & $4.09^{\mathrm{Bc}}$ & $4.16^{\mathrm{Ac}}$ & $5.03^{\mathrm{Bd}}$ & $5.79^{\mathrm{Be}}$ \\
\hline & $\mathrm{AA}+\mathrm{SACL}$ & $3.40^{\mathrm{Aa}}$ & $3.50^{\mathrm{Aa}}$ & $3.52^{\mathrm{Aa}}$ & $4.06^{\mathrm{Ab}}$ & $4.53^{\mathrm{Ac}}$ & $5.51^{\mathrm{Ad}}$ \\
\hline & $\mathrm{AA}+\mathrm{CH}$ & $3.40^{\mathrm{Aa}}$ & $3.74^{\mathrm{Bb}}$ & $4.02^{\mathrm{Bc}}$ & $4.18^{\mathrm{Ac}}$ & $4.97^{\mathrm{Bd}}$ & $5.89^{\mathrm{Be}}$ \\
\hline \multirow{4}{*}{ Coliforms } & $\mathrm{CON}$ & $2.02^{\mathrm{Aa}}$ & $2.61^{\mathrm{Bb}}$ & $2.71^{\mathrm{Bbc}}$ & $2.77^{\mathrm{Bc}}$ & $2.78^{\mathrm{Bc}}$ & $2.92^{\mathrm{Dd}}$ \\
\hline & AA & $2.02^{\mathrm{Aa}}$ & $2.49^{\mathrm{Bb}}$ & $2.65^{\mathrm{ABc}}$ & $2.68^{\mathrm{ABc}}$ & $2.72^{\mathrm{Bcd}}$ & $2.84^{\mathrm{CDd}}$ \\
\hline & $\mathrm{AA}+\mathrm{SACL}$ & $2.02^{\mathrm{Aa}}$ & $2.24^{\mathrm{Ab}}$ & $2.48^{\mathrm{Ac}}$ & $2.53^{\mathrm{Acd}}$ & $2.59^{\mathrm{Acd}}$ & $2.63^{\mathrm{Ad}}$ \\
\hline & $\mathrm{AA}+\mathrm{CH}$ & $2.02^{\mathrm{Aa}}$ & $2.47^{\mathrm{Bb}}$ & $2.52^{\mathrm{ABbc}}$ & $2.56^{\mathrm{Abc}}$ & $2.60^{\mathrm{Ac}}$ & $2.76^{\mathrm{BCd}}$ \\
\hline
\end{tabular}

${ }^{1)} \mathrm{CON}$ : Control, AA: Ascorbic acid 500 ppm, AA+SACL: Ascorbic acid 500 ppm+Na-acetate 1,500 ppm+Ca-lactate 500 ppm, AA+CH: Ascorbic acid $500 \mathrm{ppm}+$ Chitosan 7,000 ppm.

A-D: Means with different letters with a column of each storage period are significantly different $(p<0.05)$.

a-f: Means with different letters with a row of each treatment period are significantly different $(p<0.05)$. 
affected by all treatments from day 4 compared with the CON samples $(p<0.05)$. Among the treatments, samples treated with $\mathrm{AA}+\mathrm{SACL}$ had the lowest TPC from day 4 $(p<0.05)$.

Increasing trends over the storage period were also observed for lactic acid bacteria (LAB), Pseudomonas spp., and coliform bacteria. The dominant flora was LAB during the whole storage time, while the growth of Pseudomonas spp. was slightly inhibited and coliforms distinctly inhibited, probably by LAB. The counts of $\mathrm{LAB}$ were lower in the treatments than in the CON during storage time. The inhibition of LAB occurred mostly in the samples treated with chitosan, followed by those treated with AA+SACL and those treated with just AA. The growth of Pseudomonas spp. during storage was affected by the addition of organic acids or salts and chitosan in the same way as in the LAB. However, the most effective additive for suppressing the growth of Pseudomonas spp. was found to be AA+SACL. The counts of coliforms didn't exceed the level of $3.0 \mathrm{log} \mathrm{cfu} /$ $\mathrm{g}$ after $10 \mathrm{~d}$ in all samples throughout the storage. However, the growth of coliforms was slightly inhibited by the combined treatment of AA+SACL compared to the CON samples $(p<0.05)$.

The antimicrobial effect of ascorbic acid on ground meat has been reported controversially. The effect of 500 ppm sodium ascorbate on the TPC of ground beef was not shown in the study of Rhee et al. (1997). Contrarily, Kulshrestha and Rhee (1996) found the addition of 500 ppm sodium ascorbate was effective in reducing the TPC of precooked and aerobically packaged beef patties. In our experiment, the treatment of beef and pork patties with 500 ppm ascorbic acid showed antimicrobial effects as observed with the decreased counts of total aerobes, LAB, and Pseudomonas spp. over the storage period. Giroux et al. (2001) also reported that the lag phase of microbial growth was extended and the counts of total aerobes and coliforms in the beef patties were reduced by approximately $2 \operatorname{logs}$ by the addition of 5,000 ppm ascorbic acid.

The antimicrobial efficacy of organic acid and salts in meat products are affected by the acid type used, its concentration, application method, initial bacterial load, and composition of products etc. (Samelis and Sofos, 2003). Organic acid salts have antimicrobial properties against non-pathogenic and pathogenic bacteria in meat products (Bloma et al., 1998; Chen and Shelef, 1992; Miller and Acuff, 1994). For instance, lactates and acetates have proven their antimicrobial effects in ground meat prod- ucts (Maca et al., 1997; Rhee et al., 1997; Sallam and Samejima, 2004; Tan and Shelef, 2002). It might be noteworthy that a significant microbial inhibitory effect was achieved in our experiment at a relatively low concentration of organic acid salts (sodium acetate 1,500 ppm+ calcium lactate $500 \mathrm{ppm}$ ) as compared to other research in which in most cases 1-3\% concentration was applied. In this connection, it was reported that the combined use of lactate and diacetate was more effective for shelf-life extension than individual use (Adams and Hall, 1988; Jensen et al., 2003).

The antimicrobial properties of chitosan in various meat products have been well documented by other authors (Darmadji and Izumimoto, 1994; Roller, 2003; Sagoo et al., 2002). Chitosan exhibits antimicrobial activities against a wide range of food spoilage and pathogenic bacteria for which a minimum concentration of $500 \mathrm{ppm}$ is required (Kanatt et al., 2008). Georgantelis et al. (2007) have observed a significant reduction of microbial population in fresh pork sausages by the addition of 10,000 ppm chitosan. López-Caballero et al. (2005) have found that the antibacterial effect was not demonstrated when powdered chitosan $(1.5 \%)$ was mixed into fish patties with a neutral $\mathrm{pH}$. In acidic conditions, especially in $\mathrm{pH}$ values lower than 6.3 , the $\mathrm{pKa}$ of chitosan, the antimicrobial activity of chitosan increases. This is because chitosan is protonated in acidic $\mathrm{pH}$ which promotes electrostatic binding with anionic charged bacterial surfaces and resulting in elevated antimicrobial activity (Herander et al., 2001) As shown in Fig. 1, the $\mathrm{pH}$ values

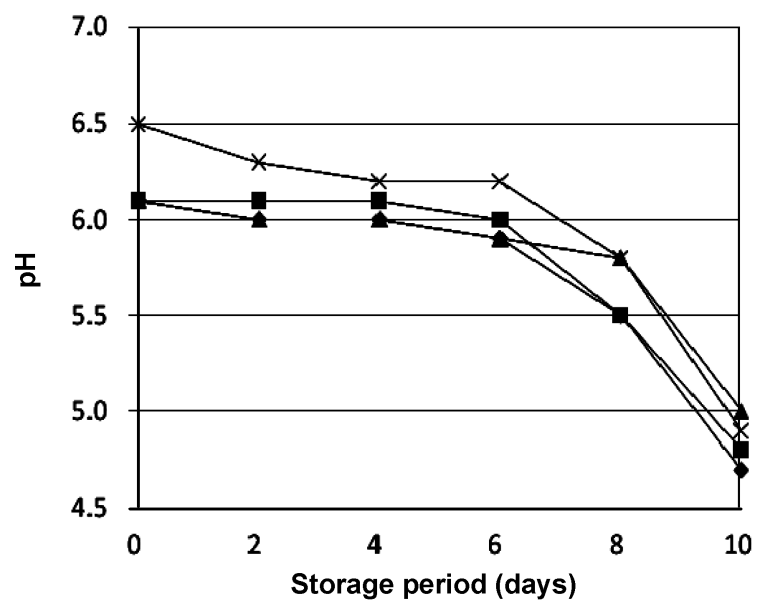

Fig. 1. Changes in pH values of case-ready packaged beef and pork patties treated with different additives during storage at $5^{\circ} \mathrm{C}$. - : Control, $-\mathbf{-}$ : Ascorbic acid $500 \mathrm{ppm}, \longrightarrow$ : Ascorbic acid $500 \mathrm{ppm}+\mathrm{Na}$-acetate $1,500 \mathrm{ppm}+\mathrm{Ca}-$ lactate $500 \mathrm{ppm}, \nsucc$ : Ascorbic acid 500 ppm+Chitosan 7,000 ppm. 
of chitosan treated samples were lower than 6.3 from day 4 ; it can be assumed that the antimicrobial activity of chitosan was strengthened by its combined use with ascorbic acid.

\section{pH, TBA, and VBN values}

Changes in $\mathrm{pH}, \mathrm{TBA}$, and VBN values during storage of beef and pork patties are shown in Fig. 1-3. The initial $\mathrm{pH}$ value of the chitosan treated samples was significantly higher than other samples which were around 6.1

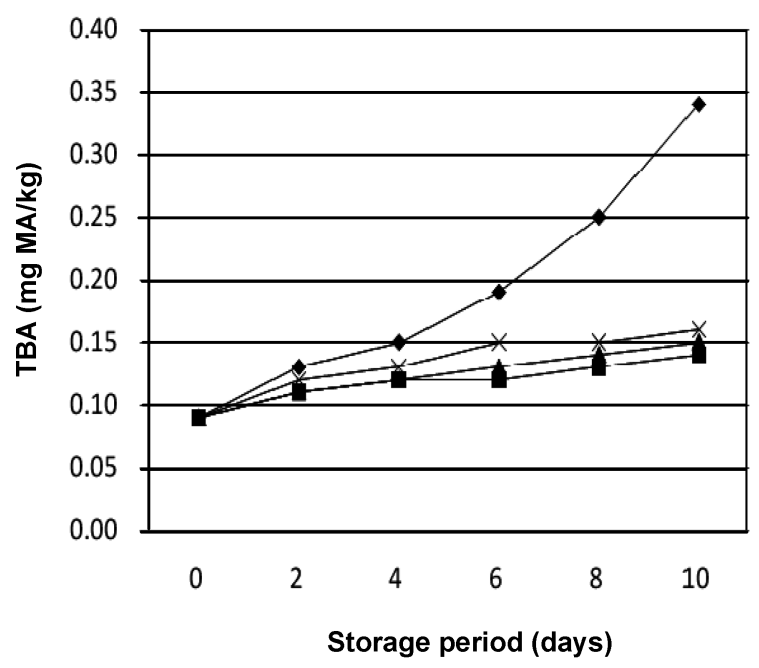

Fig. 2. Changes in thiobarbituric acid values of case-ready packaged beef and pork patties treated with different additives during storage at $5^{\circ} \mathrm{C}$. - : Control, $-\mathbf{-}$ Ascorbic acid $500 \mathrm{ppm}, \longrightarrow$ : Ascorbic acid $500 \mathrm{ppm}+$ Na-acetate $1,500 \mathrm{ppm}+\mathrm{Ca}$-lactate $500 \mathrm{ppm},-\underset{x}{ }$ : Ascorbic acid 500 ppm+Chitosan 7,000 ppm.

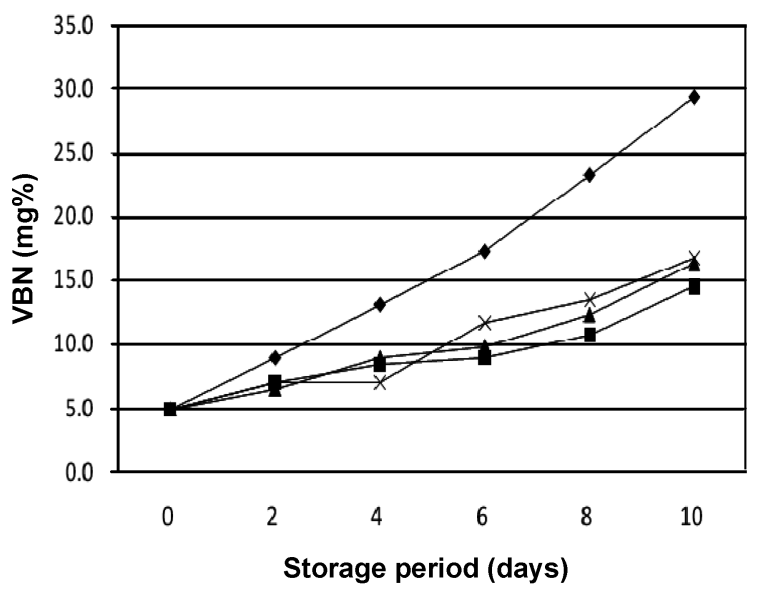

Fig. 3. Changes in volatile basic nitrogen values of caseready packaged beef and pork patties treated with different additives during storage at $5^{\circ} \mathrm{C}$ - - : Control, --: Ascorbic acid 500 ppm, - —: Ascorbic acid 500

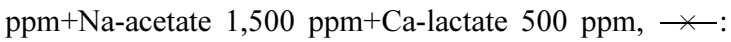
Ascorbic acid $500 \mathrm{ppm}+$ Chitosan 7,000 ppm. $(p<0.05)$. $\mathrm{pH}$ values gradually decreased over the storage in all samples (Fig. 1). This might be associated mostly with the increase of $\mathrm{LAB}$ counts during storage. The $\mathrm{pH}$ of ascorbic acid solution used in this experiment was very low ( $\mathrm{pH}$ 1.7). However, the $\mathrm{pH}$ values of samples treated with ascorbic acid, except in $\mathrm{AA}+\mathrm{CH}$ samples, were not significantly different from those of the CON samples. This could be due to the relatively low concentration of ascorbic acid (500 ppm) and the buffer capacity of meat. The $\mathrm{pH}$ values of patties treated with chitosan were significantly higher than the other samples until day 8 . This might be due to the high $\mathrm{pH}$ value (7.0) and the relatively high addition (7,000 ppm) of chitosan, and low counts of LAB. Similar trends have also been observed by others (Georgantelis et al., 2007; Jo et al., 2001).

The TBA values used as an index for the lipid oxidation increased significantly in the CON samples from $0.09 \mathrm{mg} \mathrm{MA} / \mathrm{kg}$ initially to $0.34 \mathrm{mg} \mathrm{MA} / \mathrm{kg}$ at the end of storage. The TBA values in the AA, AA+SACL, and $\mathrm{AA}+\mathrm{CH}$ samples were significantly lower than the $\mathrm{CON}$ over the storage $(p<0.05)$. Among the treated samples, there were no significant differences observed in the TBA values throughout the storage $(p<0.05)$. Darmadji and Izumimoto (1994) also reported that the use of $1 \%$ chitosan for beef patties was effective to reduce the TBA values up to $70 \%$ after $3 \mathrm{~d}$ at $4^{\circ} \mathrm{C}$.

The antioxidant activities of ascorbic acid are dependent on the concentration of ascorbic acid and Fe(III) (Lee and Hendricks, 1997). At a concentration between 200 and $300 \mathrm{mg} / \mathrm{kg}$, it acts as a prooxidant, but above this concentration it exerts an antioxidant activity (Decker and Xu, 1998). The antioxidant effects of ascorbic acid in terms of inhibiting lipid oxidation have been reported in ground patties made of beef with $500 \mathrm{ppm}$ ascorbic acid (Mitsumoto et al., 1991; Rhee et al., 1997), pork with 3,000 ppm calcium ascorbate (Moon et al., 2008), and chicken with 500 ppm ascorbic acid (Naveena et al., 2008). However, Cheng et al. (2007) found a nonsignificant reduction of TBA values in raw pork patties treated with $550 \mathrm{ppm}$ ascorbic acid. Mitsumoto et al. (2005) observed a different effect of ascorbic acid on reducing TBA values depending on its concentration and the meat species. The effect of ascorbic acid on the beef patties was not significant at the concentration of 200 ppm while it was significant at the addition of $400 \mathrm{ppm}$. Contrarily, the effect of ascorbic acid was not observed in chicken patties with the addition of either 200 or 400 ppm ascorbic acid. Most of these observations were made not for patties during storage, but directly after manufacturing. 
With the beef patties packaged in MAP $\left(70 \% \mathrm{O}_{2}+20 \%\right.$ $\mathrm{CO}_{2}+10 \% \quad \mathrm{~N}_{2}$ ), non-significant antioxidant or even prooxidant effects were observed compared to the control samples when 500 ppm ascorbic acid was added (Sánchez-Escalante et al., 2001, 2003). In our experiment, the difference in the TBA values between the CON and samples treated with ascorbic acid seemed not to be distinctive at the beginning of storage. However, the TBA values of the CON samples rose sharply with the extension of storage while their increase in treated samples was minimal.

Realini et al. (2004) pointed out that the effect of ascorbic acid on beef patties was dependent on the fatty acid composition and antioxidant content of the meat. Patties made with grass-fed beef demonstrated more stability against lipid oxidation than those made with grain-fed beef during storage for $8 \mathrm{~d}$ because of higher antioxidant contents, in spite of higher polyunsaturated fatty acid contents in the former than the latter. Based on all those observations, the effectiveness of ascorbic acid might be influenced by various factors, for instance, its concentration, the storage time, the balance between antioxidants and prooxidants (Monahan, 2000), and the gas milieu surrounding the sample.

The use of acetate/lactate or chitosan in combination with 500 ppm ascorbic acid didn't seem to have any synergistic effect on retarding lipid oxidation compared to the use of ascorbic acid only. This result was not in agreement with others who observed a synergistic effect for inhibiting lipid oxidation when ascorbic acid was used in combination with other antioxidants, for instance, tocopherol and sesamol for irradiated ground beef (Ahn and Nam, 2004), tocopherol for ground beef (Mitsumoto et al., 2006), carnosine for beef patties (Lee et al., 1999), and rosemary for beef patties in MAP (Sánchez-Escalante et al., 2003).

All samples investigated in our experiment seemed not to be affected by rancidity until the end of storage, despite the report that rancid flavor is initially detected in meat products with TBA values between 0.5 and 2.0 (Gray and Pearson, 1987). As Lee et al. (2004) and Zhao et al. (1994) indicated, lipid oxidation is not a limiting factor for aerobically stored meats because microbial spoilage or discoloration develops earlier than lipid oxidation (Zhao et al., 1994).

VBN value, which is currently used in routine monitoring of protein degradation of raw meat in Far East countries, was in the control samples initially at $5.1 \mathrm{mg} \%$ (Fig. 3). However, it increased linearly with storage time to $29.4 \mathrm{mg} \%$ at day 10. The CON samples exceeded the putrefaction criterion of $20 \mathrm{mg} \%$ for VBN value as prescribed in the Korean regulation (KFIA, 2009), at day 8. In the comparison, the VBN values of all of the treated samples were significantly lower than the CON samples

Table 3. Changes in color attributes of Hunter $L^{*}, a^{*}, b^{*}$ and hue values of case-ready packaged beef and pork patties treated with different additives during storage at $5^{\circ} \mathrm{C}$

\begin{tabular}{|c|c|c|c|c|c|c|c|}
\hline \multirow{2}{*}{ Parameter } & \multirow{2}{*}{ Treatment $^{1)}$} & \multicolumn{6}{|c|}{ Storage time (d) } \\
\hline & & 0 & 2 & 4 & 6 & 8 & 10 \\
\hline \multirow{4}{*}{$L^{*}$} & $\mathrm{CON}$ & $44.1^{\mathrm{Aa}}$ & $42.8^{\mathrm{Ab}}$ & $42.1^{\mathrm{BCc}}$ & $41 . .^{9 \mathrm{Ac}}$ & $42.1^{\mathrm{Ac}}$ & $43.6^{\mathrm{Aa}}$ \\
\hline & AA & $46.5^{\mathrm{Ca}}$ & $46.1^{\mathrm{Ba}}$ & $42.3^{\mathrm{Cb}}$ & $41.6^{\mathrm{Ac}}$ & $41.6^{\mathrm{Ac}}$ & $47.5^{\mathrm{Ca}}$ \\
\hline & $\mathrm{AA}+\mathrm{SACL}$ & $45.7^{\mathrm{Bb}}$ & $43.2^{\mathrm{Ac}}$ & $41.6^{\mathrm{Ad}}$ & $43.6^{\mathrm{Cc}}$ & $42.2^{\mathrm{Acd}}$ & $47.0^{\mathrm{BCa}}$ \\
\hline & $\mathrm{AA}+\mathrm{CH}$ & $43.8^{\mathrm{Ab}}$ & $42.8^{\mathrm{Ac}}$ & $41.8^{\mathrm{ABc}}$ & $42.6^{\mathrm{Bc}}$ & $42.1^{\mathrm{Ac}}$ & $46.1^{\mathrm{Ba}}$ \\
\hline \multirow{4}{*}{$a^{*}$} & $\mathrm{CON}$ & $11.2^{\mathrm{Aa}}$ & $9.1^{\mathrm{Ab}}$ & $6.3^{\mathrm{Ab}}$ & $6.4^{\mathrm{Ad}}$ & $5.1^{\text {Acd }}$ & $5.6^{\mathrm{Ac}}$ \\
\hline & AA & $11.6^{\mathrm{Ba}}$ & $9.8^{\mathrm{Bb}}$ & $9.7^{\mathrm{Cb}}$ & $8.4^{\mathrm{Bc}}$ & $7.7^{\mathrm{Bd}}$ & $5.8^{\mathrm{Ae}}$ \\
\hline & $\mathrm{AA}+\mathrm{SACL}$ & $12.5^{\mathrm{Da}}$ & $9.9^{\mathrm{Bb}}$ & $9.5^{\mathrm{Bb}}$ & $9.0^{\mathrm{Cbc}}$ & $8.3^{\mathrm{Cc}}$ & $5.7^{\mathrm{Ad}}$ \\
\hline & $\mathrm{AA}+\mathrm{CH}$ & $12.0^{\mathrm{Ca}}$ & $11.6^{\mathrm{Ca}}$ & $10.0^{\mathrm{Db}}$ & $9.2^{\mathrm{Cc}}$ & $8.8^{\mathrm{Cd}}$ & $6.8^{\mathrm{Be}}$ \\
\hline \multirow{4}{*}{$b^{*}$} & $\mathrm{CON}$ & $17.9^{\mathrm{Aa}}$ & $17.9^{\mathrm{Ba}}$ & $12.8^{\mathrm{Ac}}$ & $12.6^{\mathrm{Ac}}$ & $15.1^{\mathrm{Ab}}$ & $17.5^{\mathrm{Ba}}$ \\
\hline & AA & $18.7^{\mathrm{Ba}}$ & $15.9^{\mathrm{Ac}}$ & $14.5^{\mathrm{Bd}}$ & $14.5^{\mathrm{Bd}}$ & $17.3^{\mathrm{BCb}}$ & $15.1^{\mathrm{Ac}}$ \\
\hline & $\mathrm{AA}+\mathrm{SACL}$ & $19.2^{\mathrm{Ca}}$ & $17.7^{\mathrm{Bab}}$ & $17.3^{\mathrm{Cb}}$ & $17.0^{\mathrm{Cb}}$ & $16.7^{\mathrm{Bb}}$ & $15.1^{\mathrm{Ac}}$ \\
\hline & $\mathrm{AA}+\mathrm{CH}$ & $18.6^{\mathrm{Ba}}$ & $18.1^{\mathrm{Ca}}$ & $18.7^{\mathrm{Da}}$ & $18.2^{\text {Dab }}$ & $17.6^{\mathrm{Cb}}$ & $18.0^{\mathrm{Bb}}$ \\
\hline \multirow{4}{*}{ Hue } & $\mathrm{CON}$ & $57.9^{\mathrm{BCa}}$ & $63.1^{\mathrm{Cb}}$ & $63.9^{\mathrm{Cb}}$ & $63.1^{\mathrm{Bb}}$ & $71.2^{\mathrm{Cc}}$ & $72.1^{\mathrm{Bc}}$ \\
\hline & AA & $58.3^{\mathrm{Cb}}$ & $58.2^{\mathrm{Ab}}$ & $56.2^{\mathrm{Ab}}$ & $59.9^{\mathrm{Ac}}$ & $66.1^{\mathrm{Bd}}$ & $68.9^{\mathrm{Ae}}$ \\
\hline & $\mathrm{AA}+\mathrm{SACL}$ & $56.9^{\mathrm{Aa}}$ & $60.8^{\mathrm{Bb}}$ & $61.2^{\mathrm{Bbc}}$ & $62.1^{\mathrm{Bc}}$ & $63.5^{\mathrm{Ad}}$ & $69.2^{\mathrm{Ae}}$ \\
\hline & $\mathrm{AA}+\mathrm{CH}$ & $57.2^{\mathrm{ABa}}$ & $58.6^{\mathrm{Ab}}$ & $61.8^{\mathrm{Bc}}$ & $63.1^{\mathrm{Bd}}$ & $63.4^{\mathrm{Ad}}$ & $69.3^{\mathrm{Ae}}$ \\
\hline
\end{tabular}

\footnotetext{
${ }^{1)}$ Refer to Table 1.

A-D, a-f: Same as in Table 1.
} 
and maintained below the limit value. This result suggests that there was at least no visible evidence of spoilage by proteolysis in the treated samples up to the end of storage. Among the treated samples, the VBN values of patties with ascorbic acid alone were slightly but insignificantly lower $(p>0.05)$ than the other treated samples to which sodium acetate/calcium lactate or chitosan was additionally added. Therefore, the use of acetate/lactate or chitosan in addition to $500 \mathrm{ppm}$ ascorbic acid seems not to have any evidence of a synergistic effect in terms of delaying proteolysis compared to the ascorbic acid alone.

\section{Color changes}

The color changes during storage are presented in Table 3. The $L^{*}$ values for all samples showed a decreasing trend as the storage extended and increased again after 10 d. The $a^{*}$ values in all samples decreased gradually with prolonging the storage. The $b^{*}$ values tended to decrease with time except in the control samples where a sharp increase was observed. A gradual increase in the hue values was observed in all of samples with storage time. Similar results were also reported elsewhere (Banón et al., 2007; Seyfert et al., 2007). The treated samples tended to have higher $a^{*}$ values and lower hue values compared to the CON samples throughout the storage. Among the color parameters, $a^{*}$ and hue values seemed to have a good correlation with discoloration. Hue values are known to be attributed to the oxidative accumulation of metmyoglobin with time (Doherty et al., 1996). Among the treated samples, chitosan and AA+SACL samples showed a higher $a^{*}$ values compared to AA samples until day 8 . This observation is in agreement with others who reported a better color retaining property by the addition of chitosan (Darmadji and Izumimoto, 1994; Lee et al., 2003), and lactate and/or acetates (Bradford et al., 1993; Jensen et al., 2003; Seyfert et al., 2007) for the preservation of meat and meat products. Regarding the use of antioxidants as observed in this study, the results for the quality keeping property in terms of color retention show a similar trend to the development of lipid oxidation. These findings are supported by Kannan et al. (2001) who indicated that the meat pigment oxidation is positively correlated with lipid oxidation.

\section{Gas composition in the headspace of packages}

The oxygen, nitrogen and carbon dioxide concentrations in the headspace are shown in Fig. 4. The gas composition within the package of meat products can be changed depending on factors such as microbial growth, enzymatic reaction, solubility of gasses into meat and the penetration rate of gasses through packaging materials etc. The oxygen concentration was initially $19.5 \%$ which was then gradually decreased below $10.0 \%$ after $10 \mathrm{~d}$. Instead of the oxygen depletion, carbon dioxide concentration increased dramatically at the end of storage. In particular, the carbon dioxide concentration increased dramatically after $8 \mathrm{~d}$ in the control, $\mathrm{AA}$ and $\mathrm{AA}+\mathrm{CH}$ samples, while it is observed after $10 \mathrm{~d}$ in the $\mathrm{AA}+\mathrm{SACL}$ samples. These changes of the gas concentration in the extended storage might be attributed to the increased microbial population by which the carbon dioxide is produced in compensation for oxygen (Laleye et al., 1984). The rate of generated carbon dioxide might be high enough to induce accumulation in the package. The rela-
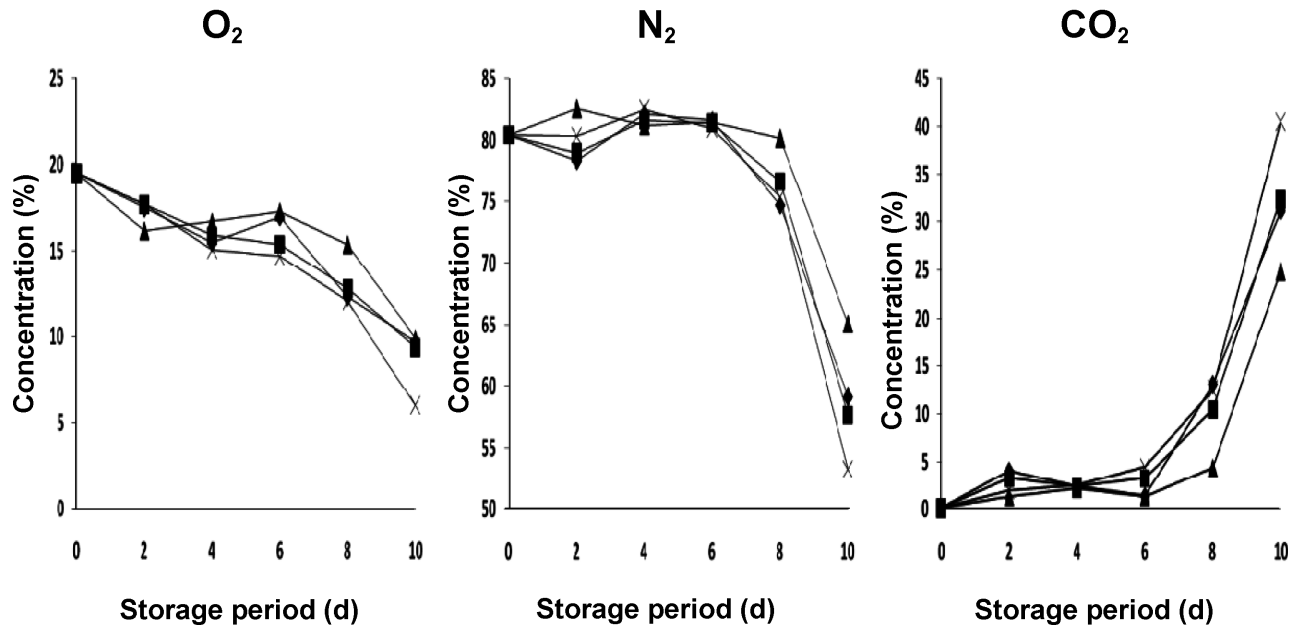

Fig. 4. Changes in gas composition in the head space of case-ready package for beef and pork patties during storage at $5^{\circ} \mathrm{C}$.

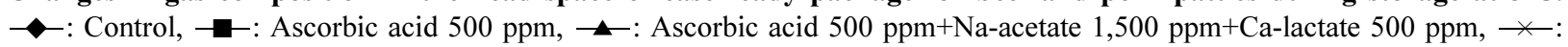
Ascorbic acid 500 ppm+Chitosan 7,000 ppm. 
tively thick tray and low gas permeability of lid film might help to create the carbon dioxide-rich atmosphere in the package with storage time. The increase of carbon dioxide in the meat package was attributed partly to the interactions of gas solubility, temperature, headspace volume, and microflora activity (Daun et al., 1971; Laleye et al., 1984). Carbon dioxide has an effect of extending the storage life of chilled meat, even though the growth of $\mathrm{LAB}$ and facultative anaerobes is not affected by carbon dioxide (Gill and Tan, 1980). The changes in the gas composition inside the packages of the patties investigated in our experiment, that is elevated carbon dioxide and reduced oxygen concentration, could not have exerted any positive effect on suppressing the microbial growth while the products were fresh enough.

\section{Sensory evaluation}

Table 4 shows a comparison of the sensory quality changes of beef and pork patties during storage. Evaluation showed a declining tendency to discolor over longer storage. The color scores of the treated samples were slightly higher than the CON samples over the storage period. Among the treated samples, the color of AA+ SACL samples was determined to deteriorate more slowly than the AA and AA+CH samples after $6 \mathrm{~d}$.

With regard to off-odor, evaluation scores for the control samples became significantly lower than the treated samples after day 8. Among the treated samples, AA+ SACL samples were evaluated to have the lowest offodor score $(p<0.05)$. At this time, the typical odor profile was described as sour-acid, stale and slightly putrid. Sour-acid aroma is commonly associated with spoilage by lactic acid bacteria and is an indication of product deterioration (Sutherland et al., 1976). Martinez et al. (2007) observed that the high degree of discoloration in pork sausage is highly associated with lipid oxidation, resulting in the decreased oxidative stability and increased off-odors during storage, especially after further processing involving addition of salt. Sensory evaluation scores below 5.0 are presumed to reduce the market value of the product. Only the AA+SACL treatment and possibly the chitosan samples preserved market quality until the 8th day.

In order to identify the best way to extend the shelf-life of beef and pork patties by preventing the development of discoloration and off-odor, the effects of adding just ascorbic acid, adding sodium acetate combined with calcium lactate, and adding chitosan were tested in patties stored at $5^{\circ} \mathrm{C}$. Compared to control samples, the additives were effective in retarding discoloration and microbial growth. Similar antimicrobial effects were noted in the ascorbic acid samples to the acetate/lactate salts or chitosan samples. The antimicrobial effect comparable to the acetate/lactate salts or chitosan samples was noted in the ascorbic acid samples. It was found that color retention, as judged by instrumental analysis based on $a^{*}$ and hue values, was enhanced by adding acetate/lactate salts and chitosan, reinforced by sensory evaluation of surface color by an experienced panel. With regard to the TBA and VBN analysis, it was found that the control samples proved to have higher values than the other treated samples. In conclusion, it was possible to extend the shelf-life of beef and pork patties by the addition of ascorbic acid, acetate/lactate salts and chitosan compared to the control. The effect was most pronounced in the acetate/lactate samples. However, any commitment to the use and concentration of appropriate additives in the recipes for beef and pork patties will have to be made on the basis of a thorough cost and benefit analysis.

Table 4. Changes in sensory attributes of case-ready packaged raw beef and pork patties treated with different additives during storage at $5^{\circ} \mathrm{C}$

\begin{tabular}{|c|c|c|c|c|c|c|c|}
\hline \multirow{2}{*}{ Parameter } & \multirow{2}{*}{ Treatment ${ }^{1)}$} & \multicolumn{6}{|c|}{ Storage time $(\mathrm{d})$} \\
\hline & & 0 & 2 & 4 & 6 & 8 & 10 \\
\hline \multirow{4}{*}{ Colour $^{2)}$} & $\mathrm{CON}$ & $8.3^{\mathrm{Aa}}$ & $7.2^{\mathrm{Ab}}$ & $6.4^{\mathrm{Ac}}$ & $5.7^{\text {Acd }}$ & $3.9^{\mathrm{Ae}}$ & $3.1^{\mathrm{Af}}$ \\
\hline & $\mathrm{AA}$ & $8.9^{\mathrm{Ba}}$ & $8.6^{\mathrm{Bab}}$ & $7.2^{\mathrm{Bbc}}$ & $6.7^{\mathrm{Bcd}}$ & $4.9^{\mathrm{Be}}$ & $3.2^{\mathrm{Af}}$ \\
\hline & $\mathrm{AA}+\mathrm{SACL}$ & $8.9^{\mathrm{Ba}}$ & $8.6^{\text {Bab }}$ & $7.1^{\mathrm{Bbc}}$ & $7.2^{\mathrm{Cbc}}$ & $5.4^{\mathrm{Ce}}$ & $3.9^{\mathrm{Bf}}$ \\
\hline & $\mathrm{AA}+\mathrm{CH}$ & $8.9^{\mathrm{Ba}}$ & $8.6^{\text {Bab }}$ & $7.1^{\mathrm{Bc}}$ & $6.7^{\mathrm{Bd}}$ & $5.1^{\mathrm{BCe}}$ & $3.9^{\mathrm{Bf}}$ \\
\hline \multirow{4}{*}{ Off-odour ${ }^{3)}$} & $\mathrm{CON}$ & $9.0^{\mathrm{Aa}}$ & $7.7^{\mathrm{ACb}}$ & $6.5^{\mathrm{Ac}}$ & $6.2^{\text {Acd }}$ & $4.2^{\mathrm{Ae}}$ & $3.3^{\mathrm{Af}}$ \\
\hline & $\mathrm{AA}$ & $9.0^{\mathrm{Aa}}$ & $8.4^{\mathrm{Bab}}$ & $7.4^{\mathrm{Bb}}$ & $6.0^{\mathrm{Ac}}$ & $4.7^{\mathrm{Bd}}$ & $3.1^{\mathrm{Ae}}$ \\
\hline & $\mathrm{AA}+\mathrm{SACL}$ & $9.0^{\mathrm{Aa}}$ & $8.2^{\mathrm{Bb}}$ & $7.3^{\mathrm{Bc}}$ & $6.2^{\mathrm{Ad}}$ & $5.1^{\mathrm{Be}}$ & $3.2^{\mathrm{Af}}$ \\
\hline & $\mathrm{AA}+\mathrm{CH}$ & $8.9^{\mathrm{Aa}}$ & $8.4^{\mathrm{Bab}}$ & $7.1^{\mathrm{ABc}}$ & $6.7^{\text {Acd }}$ & $4.9^{\mathrm{Be}}$ & $2.9^{\mathrm{Af}}$ \\
\hline
\end{tabular}

${ }^{1}$ Refer to Table $1,{ }^{2} 9$ : none, 1 : total, ${ }^{3)} 9$ : none, 1: extreme.

A - D, a-f: Same as in Table 1. 


\section{Acknowledgement}

This research was supported by Technology Development Program for ('Agriculture and Forestry' or 'Food' or 'Fisheries'), Ministry for Food, Agriculture, Forestry and Fisheries, Republic of Korea.

\section{References}

1. Adams, M. R. and Hall, C. J. (1988) Growth inhibition of food-borne pathogens by lactic and acetic acids and their mixtures. Int. J. Food Sci. Technol. 23, 287-292.

2. Ahn, D. U. and Nam, K. C. (2004) Effects of ascorbic acid and antioxidants on color, lipid oxidation and volatiles of irradiated ground beef. Radiat. Phys. Chem. 71, 149-154.

3. Banón, S., Díaz, P., Rodríguez, M., Garrido, M. D., and Price, A. (2007) Ascorbate, green tea and grape seed extracts increase the shelf life of low sulphite beef patties. Meat Sci. 77, 626-633.

4. Belcher, J. N. (2006) Industrial packaging developments for the global meat market. Meat Sci. 74, 143-148.

5. Bloma, H., Nerbrinkc, E., Dainty, R., Hagtvedt, T., Borch, E., Nissen, H., and Nesbakkend, T. (1997) Addition of 2.5\% lactate and $0.25 \%$ acetate controls growth of Listeria monocytogenes in vacuum-packed, sensory-acceptable servelat sausage and cooked ham stored at $4^{\circ} \mathrm{C}$. Int. J. Food Microbiol. 38, 71-76.

6. Bradford, D. D., Huffman, D. L., Egbert, W. R., and Jones, W. R. (1993) Low-fat fresh pork sausage patty stability in refrigerated storage with potassium lactate. J. Food Sci. 58, 1245-1253.

7. Chen, N. and Shelef, L. A. (1992) Relationship between water activity, salts of lactic acid, and growth of Listeria monocytogenes in a meat model system. J. Food Prot. 55, 574-578.

8. Cheng, J. H., Wang, S. T., and Ockerman, H. W. (2007) Lipid oxidation and color change of salted pork patties. Meat Sci. 75, 71-77.

9. Conway, E. J. (1958) Microdiffusion analysis and volumetric error. The MacMillian Co., NY.

10. Darmadji, P. and Izumimoto, M. (1994) Effect of chitosan in meat preservation. Meat Sci. 38, 243-254.

11. Daun, H., Solberg, M., Franke, W., and Gilbert, S. (1971) Effect of oxygen-enriched atmospheres on storage quality of packaged fresh meat. J. Food Sci. 36, 1011-1014.

12. Decker, E. A. and Xu, Z. (1998) Minimizing rancidity in muscle foods. Food Technol. 52, 54-59.

13. Doherty, A. M., Scheridan, J. J., Allen, P., MacDowell, D. A., and Blair, I. S. (1996) Physical characteristics of lamb primals packaged under vacuum or modified atmospheres. Meat Sci. 42, 315-324.

14. Eilert, S. J. (2005) New packaging technologies for the 21 century. Meat Sci. 71, 122-127.

15. Georgantelis, D., Ambrosiadis, I., Katikou, P., Blekas, G., and Georgakis, S. A. (2007) Effect of rosemary extract, chi- tosan and $\alpha$-tocopherol on microbiological parameters and lipid oxidation of fresh pork sausages stored at $4{ }^{\circ} \mathrm{C}$. Meat Sci. 76, 172-181.

16. Gill, C. O. and Tan, K. H. (1980) Effect of carbon dioxide on growth of meat spoilage bacteria. Appl. Env. Microbiol. 39, 317-319.

17. Giroux, M., Quattara, B., Yefsah, R., Smoragiewicz, W., Saucier, L., and Lacroix, M. (2001) Combined effect of ascorbic acid and gamma irradiation on microbial and sensory characteristics of beef patties during refrigerated storage. J. Agric. Food Chem. 49, 919-925.

18. Gray, J. L. and Pearson, A. M. (1987) Rancidity and warmed-over flavor. In: Advances in meat research. Pearson, A. M. and Dutson, T. R. (eds), Van Nostrand, NY, Vol. 3, pp. 221-270.

19. Hayes, J. E., Stepanyan, V., Allen, P., O'Grady, M. N., and Kerry, J. P. (2010) Effect of lutein, sesamol, ellagic acid and olive leaf extract on the quality and shelf-life stability of packaged raw minced beef patties. Meat Sci. 84, 613-620.

20. Helander, I. M., Nurmiaho-Lassila, E. L., Ahvenainen, R., Rhoades, J., and Roller, S. (2001) Chitosan disrupts the barrier properties of the outer membrane of gram-negative bacteria. Int. J. Food Microbiol. 71, 235-244.

21. Jensen, J. M., Robbinsa, K. L., Ryan, K. J., Homco-Ryana, C., McKeith, F. K., and Brewer, M. S. (2003) Effects of lactic and acetic acid salts on quality characteristics of enhanced pork during retail display. Meat Sci. 63, 501-508.

22. Jo, C., Lee, J. W., Lee, K. H., and Byun, M. W. (2001) Quality properties of pork sausage prepared with water-soluble chitosan oligomer. Meat Sci. 59, 369-375.

23. Kannan, G., Kouakou, B., and Gelaye, S. (2001) Color changes reflecting myoglobin and lipid oxidation in chevon cuts during refrigerated display. Small Ruminant Research 42, 67-74.

24. Kanatt, S. R., Chander, R., and Sharma, R. (2008) Chitosan and mint mixture: A new preservative for meat and meat products. Food Chem. 107, 845-852.

25. KFIA (Korea Food Industry Association). (2009) Food Code. pp. 76-80.

26. Knorr, D. (1982) Functional properties of chitin and chitosan. J. Food Sci. 47, 593-595.

27. Kulshrestha, S. A. and Rhee, K. S. (1996) Precooked reduced-fat beef patties chemical and sensory quality as affected by sodium ascorbate, lactate and phosphate. J. Food Sci. 61, 1052-1055.

28. Laleye, L. C., Lee, B. H., Simard, R. E., Carmichael, L., and Holley, R. A. (1984) Shelf life of vacuum- or nitrogenpacked pastrami: Effects of packaging atmospheres, temperature and duration of storage on physicochemical and sensory changes. J. Food Sci. 49, 832-837.

29. Lawrence, T. E., Dikeman, M. E., Hunt, M. C., Kastner, C. L., and Johnson, D. E. (2004) Effects of enhancing beef longissimus with phosphate plus salt, or calcium lactate plus non-phosphate water binders plus rosemary extract. Meat Sci. 67, 129-137.

30. Lee, B. J. and Hendricks, D. G. (1997) Metal-catalyzed oxi- 
dation of ascorbate, deoxyribose and linoleic acid as affected by phytic acid in a model system. J. Food Sci. 62, 935-938.

31. Lee, B. J., Hendricks, D. G., and Cornforth, D. P. (1999) A comparison of carnosine and ascorbic acid on color and lipid stability in a ground beef patty model system. Meat Sci. 51, 245-253.

32. Lee, H. Y., Park, S. M., and Ahn, D. H. (2003) Effect of storage properties of pork dipped in chitosan solution. J. Kor. Soc. Food Sci. Nutr. 32, 519-525.

33. Lee, K. T. and Yoon, C. S. (2001) Quality changes and shelf life of imported vacuum-packaged beef chuck during storage at $0^{\circ}$ C. Meat Sci. 59, 71-77.

34. Lee, K. T., Choi, W. S., and Yoon, C. S. (2004) Effects of micro-perforated film on the quality and shelf-life improvements of pork loins during chilled storage. Meat Sci. 66, 7782.

35. López-Caballero, M. E., Gómez-Guillén, M. E., PérezMateos, M., and Montero, P. (2005) A chitosan-gelatin blend as a coating for fish patties. Food Hydrocolloids 19, 303-311.

36. Lund, M. N., Hviid, M. S., and Skibsted, L. H. (2007) The combined effect of antioxidants and modified atmosphere packaging on protein and lipid oxidation in beef patties during chill storage. Meat Sci. 76, 226-233.

37. Maca, J. V., Miller, R. K., and Acuff, G. R. (1997) Microbiological, sensory and chemical characteristics of vacuumpackaged ground beef patties treated with salts of organic acids. J. Food Sci. 62, 591-596.

38. Martínez, L., Cilla, I., Beltrán, J. A., and Roncalés, P. (2007) Effect of illumination on the display life of fresh pork sausages packaged in modified atmosphere. Influence of the addition of rosemary, ascorbic acid and black pepper. Meat Sci. 75, 443-450.

39. McWilliam Leitch, E. C. and Stewart, C. S. (2002) Susceptibility of Escherichia coli $\mathrm{O} 157$ and non-O157 isolates to lactate. Letters in Applied Microbiology 35, 176-180.

40. Miller, R. K. and Acuff, G. R. (1994) Sodium lactate affects pathogens in cooked beef. J. Food Sci. 59, 15-19.

41. Mitsumoto, M., Faustman, C., Cassens R. G., Arnold, D. M., Schaefer, D. M., and Scheller K. K. (1991) Vitamins E and C improve pigment and lipid stability in ground beef. J. Food Sci. 56, 194-197.

42. Mitsumoto, M., O’Grady, M. N., Kerry, J. P., and Buckley, D. J. (2005) Addition of tea catechins and vitamin C on sensory evaluation, colour and lipid stability during chilled storage in cooked or raw beef and chicken patties. Meat Sci. 69, 773-779.

43. Mitsumoto, M., Faustman, C., Cassens, R. G., Arnold, R. N., Schaefer, D. M., and Scheller, K. K. (2006) Vitamins E and $\mathrm{C}$ improve pigment and lipid stability in ground beef. $J$. Food Sci. 56, 194-197.

44. Monahan, F. J. (2000) Oxidation of lipids in muscle foods: fundamental and applied concerns. In: Antioxidants in muscle foods. Decker, E. A. Faustman, C. and Lopez-Bote, C. J. (eds), Wiley, NY, pp. 3-23.

45. Moon, S. S., Kim, Y. T., Jin, S. K., and Kim, I. S. (2008) Effects of sodium chloride, potassium chloride, potassium lactate and calcium ascorbate on the physic-chemical properties and sensory characteristics of sodium-reduced pork patties. Kor. J. Food Sci. Ani. Resour. 28, 567-573.

46. Naveena, B. M., Sen, A. R., Kingsly, R. P., Singh, D. B., and Kondaiah, N. (2008) Antioxidant activity of pomegranate rind powder extract in cooked chicken patties. Int. J. Sci. Technol. 43, 1807-1812.

47. Realini, C. E., Duckett, S. K., and Windham, W. R. (2004) Effect of vitamin $\mathrm{C}$ addition to ground beef from grass-fed or grain-fed sources on color and lipid stability, and prediction of fatty acid composition by near-infrared reflectance analysis. Meat Sci. 68, 35-43.

48. Rhee, K. S., Krahl, L. M., Lucia, L. M., and Acuff, G. R. (1997) Antioxidative/antimicrobial effects and TBARs in aerobically refrigerated beef as related to microbial growth. J. Food Sci. 62, 1205-1210.

49. Rojas, M. C. and Brewer, M. S. (2007) Effect of natural antioxidants on oxidative stability of cooked, refrigerated beef and pork. J. Food Sci. 72, 282-288.

50. Roller, S. (2003) Chitosan: new food preservative or laboratory curiosity? In: Natural antimicrobials for the minimal processing of foods. Roller, S. (ed), Woodhead Publishing Limited, Cambridge, UK, pp. 159-175.

51. Sagoo, S., Board, R., and Roller, S. (2002) Chitosan inhibits growth of spoilage microorganisms in chilled pork products. Food Microbiol. 19, 175-182.

52. Sallam, Kh. I. and Samejima, K. (2004) Microbiological and chemical quality of ground beef treated with sodium lactate and sodium chloride during refrigerated storage. Lebensm.Wiss. u.-Technol. 37, 865-871.

53. Samelis, J. and Sofos, J. N. (2003) Organic acids. In: Natural antimicrobials for the minimal processing of foods. Roller, $\mathrm{S}$. (ed), Woodhead Publishing Limited, Cambridge, UK, pp. 98-132.

54. Sánchez-Escalante, A., Djenane, D., Torrescano, G., Beltrán, J. A., and Roncalés, P. (2001) The effects of ascorbic acid, taurine, carnosine, and rosemary powder on colour and lipid stability of beef patties packaged in modified atmosphere. Meat Sci. 58, 421-429.

55. Sánchez-Escalante, A., Djenane, D., Torrescano, G., Beltrán, J. A., and Roncalés, P. (2003) Antioxidant action of borage, rosemary, oregano, and ascorbic acid in beef patties packaged in modified atmosphere. J. Food Sci. 68, 339-344.

56. Seyfert, M., Hunt, M. C., Ahnström, L. M., and Johnson, D. E. (2007) Efficacy of lactic acid salts and sodium acetate on ground beef colour stability and metmyoglobin-reducing activity. Meat Sci. 75, 134-142.

57. Smulders, F. J. M. and Greer, G. G. (1998) Integrating microbial decontamination with organic acids in HACCP programmes for muscle foods: Prospects and controversies. Int. J. Food Microbiol. 44, 149-169.

58. Soultos, N., Tzikas, Z., Abrahim, A., Georgantelis, D., and Ambrosiadis, I. (2008) Chitosan effects on quality properties of Greek style fresh pork sausages. Meat Sci. 80, 1150-1156.

59. Stubbs, R. L., Morgan, J. B., Ray, F. K., and Dolezal, H. G. (2002) Effect of supplemental vitamin $\mathrm{E}$ on the color and 
case-life of top loin steaks and ground chuck patties in modified atmosphere case-ready retail packaging systems. Meat Sci. 61, 1-5.

60. Suman, S. P., Mancini, R. A., Joseph, P., Ramanathan, R., Konda, M. K. R., Dady, G., Naveena, B. M., and LopezLopez, I. (2010) Color-stabilizing effect of lactate on ground beef is packaging-dependent. Meat Sci. 84, 329-333.

61. Sutherland, J. P., Gibbs, P. A., Patterson, J. T., and Murray, J. G. (1976) Biochemical changes in vacuum packaged beef occurring during storage at $0-2^{\circ} \mathrm{C} . J$. Food Technol. 11, 171180.

62. Tan, W. and Shelef, L. A. (2002) Effects of sodium chloride and lactates on chemical and microbiological changes in refrigerated and frozen fresh ground pork. Meat Sci. 62, 2732.

63. Witte, V. C., Krause, G. F., and Bailey, M. E. (1970) A new extraction method for determining 2-thiobarbituric acid values of pork and beef during storage. J. Food Sci. 35, 582585.

64. Zhao, Y., Wells, J. H., and McMillin, K. W. (1994) Applications of dynamic modified atmosphere packaging systems for fresh red meats. J. Muscle Foods 5, 299-328.

(Received 2010.6.9/Revised 1st 2010.7.23, 2nd 2010.7.27/ Accepted 2010.7.28) 